\title{
On Political Language Ideology: Critical View of Indonesian President Speech
}

\author{
David Samuel Latupeirissa \\ Department of English Literature, STIBA Kupang, Kupang-NTT, Indonesia \\ I Ketut Darma Laksana \\ Department of Linguistics, Universitas Udayana, Denpasar, Indonesia \\ Ketut Artawa \\ Department of Linguistics, Universitas Udayana, Denpasar, Indonesia \\ I Gusti Ayu Gde Sosiowati \\ Department of Linguistics, Universitas Udayana, Denpasar, Indonesia
}

\begin{abstract}
The current research aimed to explore the political language of Indonesia's first president, Soekarno. The exploration was conducted to reveal the ideology behind Soekarno's political language. The research was focused on inspecting the language form and ideology of the language. The researchers have applied the three dimensions of analysis of the Critical Discourse Analysis theory proposed by Fairclough. The projection of language form was inspected through the analysis of the first level, while the projection of ideology was inspected through the analysis of the second level. Following that, an analysis of the third level was conducted to indicate social-political change in Indonesia as an impact of Soekarno's political language. The findings have drawn conclusion about the three main ideologies of Soekarno that have shaped nation of Indonesia. They are 'unity as the most important value', revolution as the soul of Indonesian' and, 'imperialism as the main enemy'.
\end{abstract}

Index Terms - critical discourse analysis, Fairclough's three-dimension analysis, political language, ideology

\section{INTRODUCTION}

Political language has played important roles in human civilization as the language of politics, philosophically, has existed since the beginning of the human civilization era (Cobley, 2009, p.40). Coulthard (2014) states that it has been used as a tool for performing meaning to uncover entities (p. 204). Furthermore, it has been a medium in the world (Thompson, 2005, p.5) that constructs social life (Hymes, 2005), as well as ideology (Marlina and Shakila, 2016). Based on that theoretical understanding fact, this study explores the phenomenon of how political language shapes ideology in a nation. The construction can be a means of preserving or destroying the nation. It preserves a nation when politicians use language to create positive ideology that is needed by the nation itself. By way of contrast, it destroys a nation when politicians use language as a means of grabbing power and authority for themselves without considering whether there is truth and reality in their words.

Some experts in Critical Discourse Analysis assert that most politicians use language to grab power without considering truth and reality of their words. In Indonesia, where this study has been conducted, political language is viewed as a means to cheat people. We believe that this phenomenon has occurred not only in Indonesia as an Asian country, but also in America, Europe, and African countries. In order to examine these phenomena, the authors have conducted a study on Soekarno's Political Language (SPL).

Soekarno was an Asian nationalist as well as a socialist politician (Yang and Samsudin, 2017) who proclaimed freedom for Indonesians on August, $17^{\text {th }}$ 1945. He was also the first president of Indonesia. We have chosen SPL in Indonesia because we perceive an erosion of Indonesia's national ideology, and the political value of Pancasila ${ }^{l}$, has occurred lately. It is our view, this erosion threatens to destroy what was established by the nation founders. At this level, the gap between das sein and das sollen can be viewed clearly. The strength of the national ideology and political values has been, and remains, a noble expectation for Indonesia. Unfortunately, the social phenomena that have happened lately indicate that the political value of Pancasila is getting lower, and being destroyed by other Indonesian politicians, along with the waning of patriotic ideology (cf. Ray, 2017, Bustan, 2012; Yuliono, 2013).

Furthermore, the fact that the 'highest rate of corruption in Indonesia has acted by politicians' (Tim Penyusun

${ }^{1}$ Pancasila is the Indonesia State Ideology which places national unity as its high value. 
Laporan Tahunan KPK 2016) ${ }^{2}$ is a blow to the nation's social and political life. Latupeirissa et al. (2018), based on data of Corruption Perceptions Index (2017), states that Indonesia scored 37 points out of 100 in 2017. The index of corruption averaged 25.79 points from 1995 until 2017 (Latupeirissa et al., 2018). In the past, the political language, especially SPL, was believed and accepted as a humane tool for the building and unifying of the nation. By way of contrast, nowadays, most political language is being used as a means to deceive people. That is a kind of phenomena that shows Pancasilaistic political values erosion as well.

Another urgency for this study relates to the historical value of the Indonesia nation as a part of Asian history. Through the targeted results, it is also hoped to grow the wealth of an Asian history trail. That wealth will be a valuable legacy for future generations. Similarly, the future generations, in this case, the generation of the Indonesian young, may continue to maintain the identity of Indonesia by reflecting the ideology of Pancasila which has been constructed in SPL.

\section{MATERIAL AND METHOD}

This study applies CDA theory proposed by Fairclough $(1989,1995,2005,2006)$, as its primary working hypothesis, and supported by the theory of Hermeneutics. CDA Fairclough (1989, 1995, 2005, 2006) analyzes discourse critically through three phases. The first phase is microanalysis, the second is discourse practice analysis, and the third is macro analysis (Manmeet and Bharathi, 2016).

According to Fairclough (2005), each discourse appearing in text, conversation, or whatever, cannot be seen as something natural, reasonable and neutral. He argues that discourses can be understood, as power fighting (Fairclough 2005; Latupeirissa et al., 2018). In the current study, SPL is viewed as struggling and fighting means. Further, Fairclough (1995a) states that text may be judged as domain representation, significance of the word and experience, which is open to various interpretations (Latupeirissa et al., 2018). The simplest discourse is a form of combat power (cf. Rajandran, 2014; Maros \& Nasharudin, 2016). In other words, any analysis of discourse, based on the critical views, must be related to the power dimensions.

Jørgensen et al., (2010) stated that the critical approach proposed by Fairclough has a reciprocal relationship between micro-events (verbal acts) and macro-structures. The critical approach rejects strict boundaries between micro and macro studies. Operating with the dialectics between macro and micro in critical analysis, deeper understanding of phenomena and ideology can be uncovered. This can also break down indications of social determination. To understand the discourse as a whole, three levels or aspects of analysis are needed to be conducted. The first level is text analysis, the second level is discursive practice analysis and the last is socio-cultural practice analysis.

The analysis of text levels is also known as syntactical analysis (cf. Rajandran, 2012), whilst analysis of the discursive practice and socio-cultural is called paradigmatic analysis. In this study, text level analysis examines how SPL was constructed. The analysis explores hidden text ideology (cf. Marlina and Shakila, 2016). The analysis of discursive practice, in this research, focuses on the 'whyness' factors that made Soekarno produce particular ideology in his political language, and the analysis of socio-cultural practices seeks to reveal how the ideology has changed the nation of Indonesia. Discursive practice analysis and socio-cultural practice analysis were conducted through a historical review and the application of the principles of hermeneutics.

This research views SPL as a natural phenomenon (Giorgi, 2002), that needed to be described as it was. In other words, this research proceeded with an emphasis on a phenomenological perspective of SPL (cf. Shahidi et al., 2018). The linguistic phenomenon of SPL focused on political speech texts as the corpus of data (Biber, 2006).

The corpus of Soekarno speech documents was taken from two trusted places. The first place was the office of the Indonesian Republic National Archives (IRNA) that located in South Jakarta, while the second place was the National Library of Indonesia Republic that located in Central Jakarta, Indonesia. The primary data sources were derived from the places mentioned above, since both places were the official repositories for storage of original state documents (Latupeirissa et al., 2018).

The research process was conducted following these steps and procedures. First, we took political speech texts (of Soekarno as a portrait of Soekarno's entire speech text. The total number of the documents were 919. All of them were taken from IRNA and the National Library of Indonesia Republic. They were the corpora.

Second, we selected documents from the corpora. The selection was based on technique of purposive sampling. The chosen documents were all Soekarno Political Speech (SPS) that delivered in August, $17^{\text {th }}$. There were 20 documents of SPS that were delivered from August, $17^{\text {th }} 1945$ to August, $17^{\text {th }} 1965$. The corpus was filtered into research data. The corpus of SPL, which was selected for special attention, and filtered into data, was SPS that delivered in August, $17^{\text {th }}$ 1965. The title of this speech was 'Tahun Berdikari'.

'Tahun Berdikari' was taken as the primary source for several reasons. The first reason, Soekarno himself stated that this particular August $17^{\text {th }}$ speech was the most important (Siswo, 2014; Latupeirissa et al., 2018). The second reason, the speech of 'Tahun Berdikari' was the only speech that contains a summary of all the August speeches that delivered by Soekarno from August, $17^{\text {th }} 1945$ to August, $17^{\text {th }} 1965$ (cf. Latupeirissa et al., 2018). In other words, it incorporates

\footnotetext{
2 (Indonesian: Komisi Pemberantasan Korupsi), abbreviated as KPK, is a government agency established to fight corruption. In English, it is called Indonesia's Corruption Eradication Commission
} 
the complete ideology of SPL. The third reason, in 1965, Indonesia faced critical times as the communist party maneuvered to kill a number of Indonesian generals (Latupeirissa et al., 2018). The situation was continued by a tragedy of large-scale killings as well as civil unrest which occurred over several months, targeting communist sympathizers, ethnic Chinese and alleged leftists, often at the instigation of the armed forces and government (Melvin, 2017; Latupeirissa et al., 2018). Latupeirissa et al. (2018) interpret the situation as follows. Hermeneutically, as the president, and as the founding father, with evidence of foresight, Soekarno appeared to feel and sense the crisis before the tragedy happened (Latupeirissa et al., 2018). Many consider, including the authors, that he constructed and delivered his best political speech in that year, on August $17^{\text {th }} 1965$.

Third, the research team identified data arising from research into problems. Fourth, data were selected and described in order to be analyzed applying the principles of Fairclough's CDA theory. As stated by Latupeirissa et al. (2018), the principles consist of three phases namely microanalysis, discourse practice analysis, and macro analysis (cf. Abdullah, 2014; Latupeirissa et al., 2018). Microanalysis analyzed the form of SPL, while discourse practice analyzed ideological meaning behind the language forms used in SPL as well as the whyness of these phenomena. Macro analysis briefly investigated social change (cf. Latupeirissa et al., 2018). These three analyses provided the basic framework for drawing conclusions that address scientific problems raised and discussed in the context of the research process.

\section{DISCUSSION}

In this section, we discuss the form of SPL, its ideology and the whyness or motivation that lies behind SPL. At the end of this discussion, we propose a conclusion to the question of whether SPL was destroying or preserving the nation, in this case, Indonesia. The idea proposed is based on hermeneutical principles that seek to interpret what was previously identified and discussed as evidence.

\section{A. Micro Analysis of SPL (First Level Analysis): Its Main Form.}

In the corpus, the research team found that Soekarno adopted a style of repetition which was his most identifiable characteristic form. Examples of forms of repetition occur at least 218 times in the corpus. It is the highest rank of language style phenomenon that occurs and is spread across 145 different segments. In other words, at least, in each of those segments, or in each paragraph, Soekarno used more than one example of repetition in his political speeches. In the following table, it is displayed examples of total data gained (cf. Latupeirissa et al., 2018). The repetition phenomena of SPL, that was taken from segment one to segment five, is shown in Table I.

TABLE I.

EXAMPLE OF TOTAL 218 REPETITION PHENOMENA FOUND IN SPL

\begin{tabular}{|c|c|c|}
\hline No. & Data & Segment \\
\hline 1 & Tjamkanlah saudara- saudara! Tjamkanlah, Tjamkanlah & 1 \\
\hline 2 & $\begin{array}{l}\text { Hari ini genap } 20 \text { tahun Proklamasi Kemerdekaan! Hari ini tepat } 20 \text { tahun kita } \\
\text { menjadi bangsa merdeka! Hari ini djangkap } 20 \text { tahun... }\end{array}$ & 1 \\
\hline 3 & ...Negara kita! Negara Merdeka, Negara Republik Indonesia. & 1 \\
\hline 4 & Hari ini, detik ini... & 2 \\
\hline 5 & $\begin{array}{l}\text {...rasa hatiku luluh menjadi satu dengan hati Rakyatku, dengan hati Tanah-airku, } \\
\text { dengan hati Revolusi. }\end{array}$ & 2 \\
\hline 6 & Fikiran dan perasaanku berpadu dengan fikiran dan perasaan semua... & 2 \\
\hline 7 & $d i$ kota-kota dan di desa-desa, di gunung-gunung dan di pantai-pantai & 2 \\
\hline 8 & ...dari Sabang sampai Merauke, dari Banda Aceh sampai Sukarnapura... & 2 \\
\hline 9 & Hari ini..., hari ini..., hari ini..., hari ini..., hari ini..., hari ini... & 2 \\
\hline 10 & $\begin{array}{l}\text {... bukan Sukarno, bukan Subandrio, bukan Ali, bukan Idham, bukan Aidit, bukan } \\
\text { Dadap, bukan Waru, bukan Suto, bukan Noyo, bukan Sarinah, bukan Fatimah... }\end{array}$ & 2 \\
\hline 11 & $\begin{array}{l}\text {...bukan Kepala Negara, bukan Menteri, bukan pegawai, bukan buruh, bukan } \\
\text { petani, bukan nelayan, bukan mahasiswa, bukan seniman, bukan sarjana, bukan } \\
\text { wartawan... }\end{array}$ & 2 \\
\hline 12 & $\begin{array}{l}\text {... bukan semata-mata politik, bukan melulu ekonomi, bukan hanya kebudayaan, } \\
\text { bukan mligi ilmu, bukan militer thok... }\end{array}$ & 2 \\
\hline 13 & Allahuakbar, Allahuakbar, Allahuakbar & 3 \\
\hline 14 & Kalau hari ini..., dan kalau hari ini.... Dan kalau di dunia ini... & 4 \\
\hline 15 & Aku bangga..., aku bangga & 4 \\
\hline 16 & ... mencerca kita, mengejek kita, mentertawakan kita... & 4 \\
\hline 17 & ...memang beginilah..., memang beginilah... & 4 \\
\hline 18 & Resapkanlah, endapkanlah, renungkanlah & 5 \\
\hline 19 & Tergantung..., tergantung... & 5 \\
\hline 20 & Manakala..., manakala..., manakala..., manakala..., manakala..., & 5 \\
\hline 21 & Kita melempem..., kita lembek..., kita menjerah... & 5 \\
\hline 22 & 200 tahun..., 200 tahun..., 200 tahun... & 5 \\
\hline 23 & ...bukan apa- apa,... bukan apa- apa... & 5 \\
\hline
\end{tabular}

As shown in the above table, it is apparent that the total number of repetitions significantly exceeded the number of segments contained in the text of SPL. As the main characteristic of SPL form was identified as repetition, further examination of this phenomenon was undertaken through the use of the computer software WordSmith 7. The program 
identified lexicons that were used repeatedly by Soekarno.

Using WordSmith 7, four main categories of repeated lexicons were identified. They are 'yang', 'kita', 'Indonesia', and 'memberikan'. 'Yang' was the most highly ranked lexicon that was used repeatedly by Soekarno. It occurs 383 times in SPL. It occupies $3.24 \%$ of the corpus. Semantically, 'yang' is the only Indonesian conjunction word - 'that', 'who', 'which', 'where' - that acts as preposition of placement in relative clauses. It is used to explain something.

After 'yang', the personal pronoun 'kita' is the next highest ranking word used by Soekarno. 'Kita' means ' we', or ' $u$ ' ' in English. It appears 371 times, and occupies $2.14 \%$ of the corpus. On a different side, 'Indonesia' is the highest ranking noun used by Soekarno. It is used 121 times occurring in 1.02\% of the corpus. The last, 'memberikan' is the highest ranking verb that was used by Soekarno. Semantically, 'memberikan' is a verb that means 'give' in English.

'Yang', 'Kita', 'Indonesia', and 'Memberikan', the words used repeatedly by Soekarno, mirror his personality. Hermeneutically, Soekarno was a politician who used language to explain. His explanations were offered because many Indonesian people in the past did not have sufficient understanding of many things. Instead of commanding people, Soekarno chose to offer explanations using 'yang'. The authors surmise that if the highest ranked word in Soekarno's lexicon is a verb, then it might be concluded that Soekarno was a politician who just commanded people.

The personal pronoun 'kita' (we/ us) that was often repeated by Soekarno, hermeneutically reflects Soekarno as a politician who did not only think of himself. What he did was not only for himself but for all people's sake. Again the authors surmise, that if the personal pronoun that was most often repeated by Soekarno was ' $I$ ', then it might be concluded that Soekarno was a selfish politician. Our interpretation of the use of 'kita' is supported by the finding of another word, a noun, that was often repeated by Soekarno. The other noun was 'Indonesia'.

As 'Indonesia' was the highest ranked noun repeatedly used by Soekarno, it reflects the thought that most occupied Soekarno's mind. The thing that was most consistently present in Soekarno's thinking was Indonesia. Soekarno did not only think of his position. Finally, Soekarno often repeated the verb 'memberi' (give/ giving). Our other interpretation is based on the repeated verb of 'memberi' (give/ giving). Relating to the context, Soekarno often delivered speeches to motivate all Indonesian people to offer or to give everything that could be given for the sake of Indonesia. Here, Soekarno taught people to care for others. In fact, when the history of Soekarno's struggle is examined, we find that he did not only speak or teach people to give something for the nation, he personally demonstrated a life of offering and giving. It showed his true struggle in the political world.

Based on the analysis of SPL's main form, it can be stated that it was Soekarno's normal pattern to offer explanation to teach Indonesian people. His teaching was given for the sake of the people of Indonesia, not for his own sake. His teaching was mainly motivating people to give something for the betterment of the nation.

\section{B. Second Level Analysis of SPL: Its Ideologies and Motivation}

Based on examination of the corpus, it is found that a style of repetition was the main characteristic of SPL ${ }^{3}$. Besides the repeated lexicons, there is a pattern of repeating certain topics. Our examination found three main topics that were repeated by Soekarno (cf. Latupeirissa et al., 2018). The first topic was unity, the second was revolution, and the third was imperialism and capitalism. This phenomenon provides a base for further analysis, in particular-discourse practice analysis and macro analysis, that relates to ideology and motivation, as well as social change.

The findings reflect ideologies that lay behind SPL. The ideologies are: 1) unity as the most important thing for Indonesian, 2) revolution as Indonesian soul, and 3) Imperialism and Capitalism is Indonesia's main enemy (cf. Latupeirissa et al., 2018). In 43 segments of the 145 segments, Soekarno discusses theme of unity as a very most important thing for the Indonesian people (Latupeirissa et al., 2018). In the whole text, the theme of unity dominates $30 \%$. Semantically, as stated by Latupeirissa et al. (2018), there are 119 lexicons that related to the topic of unity as the most important thing for Indonesian people. Latupeirissa et al. (2018) state that the lexicons were used to persuade people to be united. The persuasion was constructed by Soekarno because Indonesia, historically, is a multi-racial nation, a multi-religious nation, as well as a multi-cultural nation (Sa'idi, 2017; Latupeirissa et al., 2018). Indonesia, easily, could be separated due to the phenomena (Rosana, 2017).

The second main ideology that was identified, was about revolution in the Indonesian soul. It is found that 39 segments, talking about revolution, were constructed by Soekarno. It features in $27 \%$ of the whole text (Latupeirissa $e t$ al., 2018). The main point of these segments is that 'revolution must be sustained and continually lived out by all Indonesian people'. It is also found that, as also has been stated by Latupeirissa et al. (2018), there are 204 lexicons which have semantic relationship to the topic of revolution. 164 lexicons are related to the word 'revolution', and 40 lexicons are related to the word 'revolutionary'. The first ideology about unity, and the second ideology about revolution, are repeatedly expressed in SPL (Latupeirissa et al., 2018).

The third ideology, as identified, was 'imperialism and capitalism as the main enemy of the Indonesian people' (cf. Latupeirissa et al., 2018). Similar to the statement of Latupeirissa et al. (2018), the total construction of segments that speak about it was 31 segment. It features in $22 \%$ of the text as a whole (Latupeirissa et al., 2018). Furthermore, from the semantical point of view, it is found that there are 76 lexicons which relate to ideology of fighting imperialism and capitalism. Latupeirissa et al. (2018) present the following chart to show ideologies of SPL.

\footnotetext{
${ }^{3}$ The discussion about repetition as the main characteristic of SPL, in general, has been presented in an article entitled "Repetition in Indonesian Political Language" (Latupeirissa et al., 2018). It is needed to be referred as a 'mirror' of ideology of SPL.
} 


\title{
SPL IDEOLOGIES
}

\author{
Unity as the most important thing \\ - Revolution as Indonesian soul \\ Imperialism and capitalism as Indonesian main enemy \\ Other topics
}

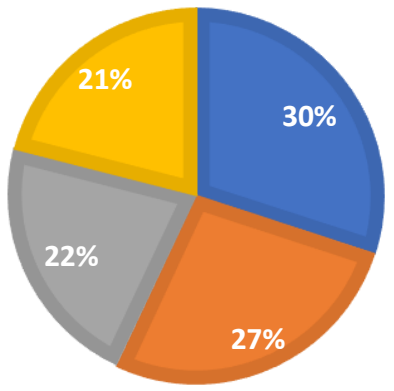

Other topics, collectively comprising $21 \%$, discus about: (1) history of the Indonesian nation, (2) thanksgiving for many positive aspects that have been given to Indonesian people, (3) the spirit of struggling in gaining freedom, (4) the meaning of freedom, (5) do not give up in facing difficulties, (6) nationalism, (7) the spirit of independence, (8) real leadership, (9) culture, (10) spiritual braveness, and (11) the ideology of marhaenism (cf. Latupeirissa et al., 2018). The eleven ideas above, overall, are only $1.9 \%$ of the SPL. In other words, they are not dominant in the text (Latupeirissa $e t$ al., 2018). The dominant ideas, or the main ideologies, are 'unity as the most important thing for Indonesians', 'revolution in the Indonesian soul', and 'Imperialism and Capitalism as Indonesia's main enemy'.

\section{Macro Analysis of SPL (Third Level Analysis): Its Impact}

Analysis of SPL's impact is a part of macro analysis in Fairclough's theory. In analyzing the impact, we adopted the method of interpretation based on the principles of hermeneutics. Hermeneutics interprets phenomena by looking at historical review. In the historical review, the team identified some changes in Indonesian socio-culture. It is asserted, that these changes may be explained by the impact of SPL's ideologies. Herewith we display two impacts.

Firstly, SPL has impacted the way Indonesian people communicate with each other. With the ideology of unity, Indonesian people have experienced a change in the way they communicate, namely in terms of language. From different ethnic, racial and cultural backgrounds, there were, and are, a lot of different languages used in communication. Tondo (2009) states that there are at least 742 different local languages in Indonesia. These language differences represented a challenge, a gap in unity. However, Soekarno, as one of the founders of Indonesia, did not give up working to unify the nation. He continued to change the way people communicated. Finally, Indonesian people began to use Indonesian language as the language of unification.

As recorded in Asian history, Indonesian language as a unifying tool was initiated by the momentum created by the youth oath on October $28^{\text {th }}, 1928$. The momentum birthed in this historic event was one of the seeds of Indonesian Independence. It was carried out through unity. However, it is difficult to deny that the momentum of the youth oath as a momentum for the birth of a unifying language did not immediately result in causing the entire nation to communicate by using the Indonesian language. It took a struggle, with a strong determination to continue the noble ideals contained in the oath of youth. This struggle, which was carried out by Soekarno, has continuing to spread the ideology of unity as the centrally important thing. Since the proclamation of Indonesian independence on August $17^{\text {th }} 1945$, the Indonesian people began to use Indonesian language more often. Increasingly over many years, the presentation of the use of Indonesian language by Indonesian people has grown to be higher than in the past (cf. Cohn \& Ravidranath, 2014).

Secondly, the ideology contained in SPL has brought a change in the way of life of the Indonesian people. The ideology here is 'Imperialism and Capitalism as the main enemy of Indonesia'. Historically, colonialism, constructed by European imperialists, has influenced the way of life of many Indonesian people (cf. King, 2016). Therefore, in his speech, Soekarno offended and denounced people who were westernized.

Next, in the Indonesian history of the early days of independence, there were many Indonesians who were proud to speak Dutch or English compared to speaking in Indonesian. Some people tended to feel more honored if they were friends of Europeans rather than being friends of their fellow Indonesians.

The western lifestyle adopted by Asian people, in this case, Indonesians, as already mentioned above, was destructive, because it did not reflect nationalism. This is what Soekarno opposed. In the end, gradually, Indonesian people have experienced a change in their way of life. In addition, Indonesian people began to use Indonesian language with pride, and people also began to work hard to give meaningful expression to Indonesia's independence. Gradually, Indonesians 
have found their real identity as Asian people.

\section{CONCLUSION}

Examining what have been discussed above, we conclude the following points. First, the main form of SPL is a style of repetition. The words that were commonly repeated by Soekarno were 'Yang', 'Kita', 'Indonesia', and 'Memberikan'. These four words have revealed Soekarno's character and his purpose in using political language. The character he lived and the purposes of his political language were to build and to preserve Indonesia.

Furthermore, by examining text domination, we identified ideologies behind SPL. The ideologies support what we have stated before. Soekarno, who was an Asian politician as well as the founder and the first president of Indonesia, tried his best to sustain Indonesia. As a result of SPL's main form and ideology, Indonesia has become a better nation. This shows that not all political language is used to cheat people.

Thomans \& Wareing (1999) have stated that political language in any speech, through indirect manipulation of language, is mostly intended to cheat people. In contrary, this research has shown that not all political language is used for manipulation. It is undeniable that a skillful speakers of political language, one of them is Soekarno, are able to influence the preconceptions, views, ambitions and fears of the public (Fairclough, 1989). They can persuade people to accept false statements as true postulates, or even to support policies conflicting with their interests. But, as we have found, Soekarno played the persuasion skills not for himself, but for humanity aims. Finally, the result of the current research is proposed to be a mirror for other politicians, especially Asian politicians. We hope that the politicians may use language to build, to sustain, and to preserve their nation. This would be a valuable action for humanity.

\section{ACKNOWLEDGMENTS}

This study was financed by The Ministry of Research, Technology, \& Higher Education of Indonesia.

\section{REFERENCES}

[1] Abdullah, F. S. (2014). Mass Media Discourse: A Critical Analysis Research Agenda. Pertanika J. Soc. Sci. \& Hum, 22 , 1-18.

[2] Biber, D. (2006). University language: A corpus-based study of spoken and written registers (Vol. 23). Netherlands: John Benjamins Publishing.

[3] Bustan F. (2012). Politisi Selalu Berbohong. Opini in http://optimisme4all.blogspot.co.id/2012/09/politisi-selaluberbohong.html. Retrieved in February, $17^{\text {th }} 2017$.

[4] Cobley, P. (Ed.). (2009). The Routledge companion to semiotics. London: Routledge.

[5] Cohn, A. C., \& Ravindranath, M. (2014). Local languages in Indonesia: Language maintenance or language shift. Linguistik Indonesia, 32(2), 131-148.

[6] Coulthard, M. (2014). An introduction to discourse analysis. London: Routledge.

[7] Corruption Perceptions Index/. (2017). Indonesia Corruption index by Transparency International in https://tradingeconomics.com/indonesia/corruption-index. Retrieved in September, $20^{\text {th }} 2018$.

[8] Donnelly, K. P. (2009). The rhetoric of reform: examining the role of political language in Rhode Island's health care debate. Dissertation. Massachusetts: Northeastern University.

[9] Fairclough, N. (1989). Language and Power. New York: Longman Group.

[10] Fairclough, N. (1995a). Critical Discourse Analysis: The Critical Study of Language. London: Longman.

[11] Fairclough, N. (1995b). Media Discourse. London: Edward Arnold.

[12] Fairclough, N. (2003). Analysing Discourse Norman Fairclough: Textual Analysing for Social Research. London : Routledge.

[13] Fairclough, N. (2005). Analyzing Discourse. Textual Analysis for Social Research. London: Routledge.

[14] Fairclough, N. (2006). Discourse and Social Change. Cambridge: Polity Press.

[15] Giorgi, A. (1997). The theory, practice, and evaluation of the phenomenological method as a qualitative research procedure. Journal of phenomenological psychology, 28(2), 235-260.

[16] Hymes, D. (2005). Models of the interaction of language and social life: toward a descriptive theory. Intercultural discourse and communication: The essential readings, 4-16.

[17] Jupriono, D. (2010). Analisis Wacana Kritis Latar Historis dalam Pidato Kenegaraan Presiden Susilo Bambang Yudhoyono. Jurnal Parafrase, 10(2), 38-49.

[18] Jørgensen, M. W., \& Phillips, L. J. (2002). Discourse analysis as theory and method. California: Sage.

[19] King, V. T. (2016). Conceptualising culture, identity and region: Recent reflections on Southeast Asia. Pertanika. Journal of Social Sciences and Humanities, 24(1), 25-42.

[20] Latupeirissa, D. S. (2014). Diskriminasi Gender Dalam Penggunaan Bahasa Indonesia Di Surat Kabar Pos Kupang Dan Timor Express: Sebuah Analisis Wacana Kritis. Unpublished Theses. Kupang: Universitas Nusa Cendana.

[21] Latupeirissa, D. S., Laksana, I. K. D., Artawa, K., \& Sosiowati, I. G. A. G. (2018). Repetition in Indonesian Political Language. International Journal of Linguistics, Literature and Culture, 4(6), 72-80.

[22] Marlina Jamal and Shakila Abdul Manan. (2016). An ideological construction of the indigenous community: The Orang Asli as portrayed in The Star newspaper. KEMANUSIAAN the Asian Journal of Humanities 23(Supp. 2): 39-62, https://doi.org/10.21315/kajh2016.23.s2.3.

[23] Manmeet Kaur and Bharathi Mutty. (2016). The commodification of Islam?: A critical discourse analysis of halal cosmetics brands. KEMANUSIAAN the Asian Journal of Humanities 23(Supp. 2): 63-80, https://doi.org/10.21315/kajh2016.23.s2.4.

[24] Melvin, J. (2017). "Mechanics of Mass Murder: A Case for Understanding the Indonesian Killings as Genocide". Journal of Genocide Research. 19 (4): 487-511. https://doi:10.1080/14623528.2017.1393942. 
[25] Maros, M., \& Nasharudin, S. N. S. (2016). Analysis of interaction and institutional power relations in MH370 press conferences. Pertanika Journal of Social Science and Humanities, 24(February), 169-180.

[26] Oktarini, W. (2014). Tindak Tutur dan Gaya Bahasa Dalam Naskah Pidato Pelantikan Presiden Amerika. Unpublished Theses. Yogyakarta: Universitas Gadjah Mada.

[27] Rajandran, K. (2012). A Systemic Functional Linguistic Approach to University Course Guides. Pertanika Journal of Social Sciences \& Humanities, 20(2), 505-518.

[28] Rajandran, K. (2014). The Discursive Representation of Companies in Malaysian Business Magazines. Pertanika Journal of Social Sciences \& Humanities, 22(2), 489-505.

[29] Ray, A. (2017). Karna-Kunti Sambad: Tagore's Politics of Translation and Transcreation. The Appolonian Journal of Interdisciplinary Studies, 3(1\&2), 53-59.

[30] Rosana, E. (2017). Eksistensi Pancasila sebagai kontrak sosial umat beragama. Jurnal tapis, 13(2), 1-17.

[31] Sa'idi, R. (2017). Urgensi menjaga kemajemukan dan toleransi dalam era demokrasi. Jurnal tapis, 13(2), 74-90.

[32] Shahidi, A. H., Shaid, N. A. N., Yusop, M. S., Maros, M., \& Aman, R. (2018). Fenomena Sosiobudaya Orang Asli Kanaq Dalam Penguasaan Bahasa Melayu: Satu Tinjauan Awal (Sociocultural Phenomenology Of Kanaq Aboriginal In Mastery Malay Language: A Preliminary Study). e-Bangi, 15(5), 145-156.

[33] Sidabutar, S. C. (2014). Pencitraan Politik Aburizal Bakrie Dalam Teks Pidato Mendaki Semeru Dan Teks Pidato Indonesia Dalam Mimpi Saya. Jurnal E-Komunikasi, 2(2), 1-11.

[34] Siswo, I. (2014). Panca Azimat Revolusi: Tulisan, Risalah, Pembelaan, \& Pidato Sukarno 1926- 1966. Jakarta: KPG.

[35] Sosiowati, I. G. A. G. (2013). Kesantunan Bahasa Politisi dalam Talk Show di Metro TV. Unpublished Disertasi. Denpasar: Univesitas Udayana.

[36] Tannen, D. (2007). Talking Voices. Cambridge \& New York: Cambridge University Press.

[37] Thompson, P. A. (2005). Spoken language corpora. In: Wynne, M. (ed.) Developing linguistic corpora: a guide to good practice. AHDS guides to good practice. Oxbow, Oxford, pp. 59-70. ISBN 9781842172056.

[38] Thomans, L., \& Wareing, S. (1999). Language, Society and Power. London: Routledge.

[39] Yang, A.J.A. and Samsudin, M. (2017). Polemik aliran sosialis Marxisme dalam gerakan nasionalisme dan pembangunan politik radikal Melayu, 1925-1948. KEMANUSIAAN the Asian Journal of Humanities 24(2): 31-58, https://doi.org/10.21315/kajh2017.24.2.2.

[40] Tim Penyusun Laporan Tahunan KPK 2015. (2016). Laporan Tahunan KPK Tahun 2015. Jakarta: Komisi Pemberantas Korupsi.

[41] Tondo, H. (2009). Kepunahan Bahasa-Bahasa Daerah: Faktor Penyebab dan Implikasi Etnolinguistis. Jurnal Masyarakat dan Budaya, 11(2), 277-296.

[42] Yuliono, A. (2013). Kepercayaan Masyarakat Pada Partai Politik. DIA: Jurnal Ilmiah Administrasi Publik, 11(01), $173-184$.

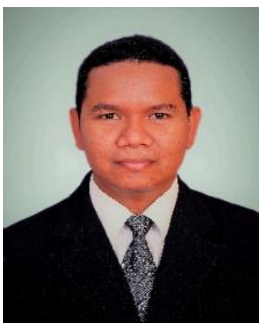

David Samuel Latupeirissa is a lecturer in STIBA Kupang, Indonesia. In STIBA, he teaches Discourse Analysis and Semantics. The subjects have also been his interest in conducting researches. His researches have been published in several reputable International journals as well as presented in International conferences. Currently, $\mathrm{He}$ is studying at Doctoral program of Linguistics at Universitas Udayana Denpasar, Bali- Indonesia. His dissertation, that is being written, entitled 'Soekarno Political Language: A Critical Discourse Study'.

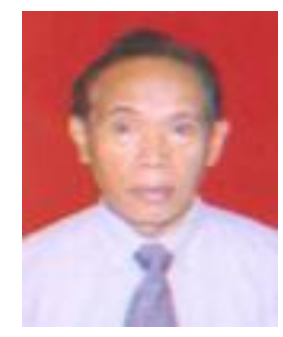

I Ketut Darma Laksana is a senior lecturer as well as a Professor in Universitas Udayana Denpasar, Indonesia. $\mathrm{He}$ is active in conducting researches related to morphology and Discourse Analysis. His researches have been published in some reputable International journals, and presented in some International Conferences.

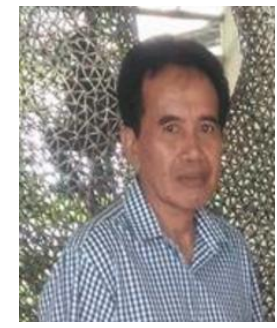

Ketut Artawa is a Professor of linguistics in Universitas Udayana Denpasar, Indonesia. He is a senior researcher who is known not only in Indonesia, but also in many places around the word. Currently, he is the head program of Doctoral Program of Linguistics at Universitas Udayana Denpasar, Bali. 


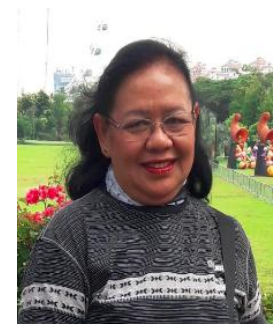

I Gusti Ayu Gde Sosiowati is an associate Professor of Linguistics. Her interest is in Political Language. Currently, she is teaching in Universitas Udayana Denpasar, Indonesia. She has conducted a lot of researches related to the field of Discourse. 